\title{
Unstable Empire: US business in the international economy
}

\author{
Arthur MacEwan
}

$I$

Throughout the 1970s and, now, on into the 1980s, while the severe disarray of the domestic US economy has been periodically masked by the recoveries that follow each bout of recession, the disorder of the international economy has been continually apparent. Nonetheless, one set of central actors in international economic affairs has maintained an image of power and stability. The US-based multinational firms Citibank, ITT, GE, Exxon and the others - are seen by their apologists and critics alike as bastions of power, dynamic actors running the world economy.

To be sure, these US-based multinational firms are extremely powerful, managing resources, commerce and capital on a vast scale. Yet they are not in control'. In spite of their power, they have not been able to run the international economy effectively. The old image of these corporations as possessing near omnipotence is no longer appropriate (if in fact it ever was). Ironically, the multinationals' earlier successes prepared the way for their current problems problems that are at the root of the general instability of the international economy in the $1980 \mathrm{~s}$.

Consider, for example, the case of ITT. An aggressively managed multinational conglomerate, deeply involved in the economic and political affairs of other nations, ITT became in the late 1960s and early 1970 s a prime symbol of US international power. As economic stagnation and inflation disrupted the world economy in the mid-1970s, however, ITT ran into considerable difficulties. Foreign governments restricted its operations; foreign based competitors made inroads in its markets; and the company encountered internal management deficiencies in handling its extensive empire. ITT's international business empire still stands, but at the same time its problems have continued. These problems were underscored in late 1981 when the loss to Japan's Nippon Electric of a major switching gear contract in Brazil led ITT to terminate its 53 year-old operation in that largest of Latin American markets.
The rise and then instability of ITT reflects experience common to many US-based multinationals. It is now clear that just when US multinationals appeared to be sitting on top of the world, their expansion rate was beginning to ebb. During the 1950s and 1960s the value of assets held abroad by US corporations grew at a rate of seven to eight per cent a year (corrected for inflation) - a rate of growth much higher than that of the domestic economy. In the late 1960s and through the 1970s, however, US multinationals' assets abroad were growing at only about four per cent a year hardly more rapidly than the domestic economy.

Paradoxically, while difficulties abroad have slowed the foreign growth of US companies, even greater difficulties with maintaining earnings in the domestic economy have increased the relative importance of foreign-source profits. In the $1960 \mathrm{~s}$, profits coming from foreign investment accounted for, on average, about 14 per cent of post-tax US corporate profits; in the 1970 s, that figure had jumped to 21 per cent. Ford Motor Company provides an extreme example that dramatises US firms' growing reliance on their foreign profits. In the late $1960 \mathrm{~s}$ and early $1970 \mathrm{~s}$, Ford typically obtained some 20 per cent of its profits from foreign operations. During the 1974 to 1978 period, with the mid-decade slump, on average 50 per cent of Ford's profits came from abroad. Then, from 1979 to 1983, Ford continually ran losses in the US that were offset by foreign-source profits (though overall the company still ran losses in 1980, 1981 and 1982). In general, we have the ambiguous situation where, on the one hand, stagnation and instability have led US concerns to hold back the expansion of their foreign operations, but, on the other hand, they have become more dependent on those foreign operations.

It is time to start recognising the real position of US business in the international economy. While USbased multinational firms remain extremely powerful, they also share the instability of the international economy; indeed, their operations are a central part of 
that instability. Accordingly, it secms appropriate to characterise the international operations of US business as constituting an unstable empire.

My primary purpose in this essay is to establish the validity of this characterisation by examining three of its aspects: the focus of US business operations abroad on the pentration and control of markets; the extremely large and rapid growth of US-based international banking: and the increasing strains on the organisational structures of the multinational firms. These issues will be taken up in the following three sections. Moreover. in analysing these issues. I want to develop the hypothesis that the current instability of the US business empire has arisen as a consequence of the great success achieved earlier by US corporations abroad: current weakness and earlier strength are two parts of the same process. In the final section I will consider some of the implications of my argument and suggest how they offer a basis for a critique of both conservative programmes to 'revitalise' the economy and liberal strategies directed toward 'reindustrialisation'.

\section{II}

Some insight into the nature of US business operations abroad can be gained from a Business Week story of 17 May 1982, regarding the activities of US computer firms in Mexico:

US computer makers are rushing to set up factories in Mexico before the government slams the foor on the country's fast-growing market. Responding to Mexico City's recent decision to tighten quotas on computer imports as well as pressure computer makers to produce locally. some 45 companies have applied to make computers and peripheral equipment in Mexico. In late March. HewlettPackard Co became the first foreign company to announce that the Mexican Industry Secretariat ... has given it the go-ahead ... Hewlett-Packard was allowed 100 per cent ownership of its Guadalajara plant only when it promised to use a high proportion of Mexican-made components . . 'Developing local suppliers will be a tough job', says Richard S. Love, the company's director of international marketing. As for sophisticated parts. such as integrated circuits, 'nobody in Mexico is making the right ones now', he says. Thus Hewlett-Packard will concentrate at first on buying relatively simple components, including plastics, transformers, and sheet metal for cases.

This particular story is interesting because the international operations of the computer industry are often portrayed in a very different light. We usually hear about the dependence of the computer industry on cheap foreign labour for the production of microchips and other compontents. The activities described in the Business Week story arc. however. more typical of the international opcrations of US business. The issue is markets. As they did in Europe in the 1950s and 1960s. US companies accept the pressures and limits placed on them by the Mexican Government if they have a free hand to invest as a means of obtaining access to and control of the market. The cheap labour of Mexico is of secondary intcrest to the companies. Indeed, as the story suggests. the low technological level of the Mexican economy restricts the firms because they cannot always obtain the inputs they need.

To obtain confirmation that markets and not cheap labour - and. in fact. not even raw materials - are the main part of the game for US-based multinationals, we need only look at the location of their expansion. First and foremost during the last 30 years. the companies have expanded in Europe. In 1950 only 15 per cent of the assets held abroad by US-based firms were in Europe; by 1980. 45 per cent of their assets were in Europe. In part this growth was accounted for by the tremendous expansion of European manufacturing in response to the rapidly developing market. In addition. the European market attracted investment by the US oil companies. as they shifted the principal source of their profits 'downstream' from the control of well-head operations to the control of markets.

Also. contrary to a widely held misconception. the expansion of multinationals in the poor countries has not taken place most where lábour is cheapest. Indeed, the expansion has been greatest where markets have been largest and most rapidly growing. Within Latin America, for example. US investment in manufacturing has become increasingly concentrated in Brazil and Mexico. the nations with large. rapidly growing markets. not the nations with the cheapest labour.

The sales pattern of foreign ma nufacturing subsidiaries of US firms also indicates that the firms are drawn to invest in othcr nations in order to gct at markets. Were the firms drawn abroad by cheap labour. we would expect that a sizable portion of their sales would be exports back to the US market. Instead. US manufacturing subsidiaries abroad are. by and large, selling in the markets where they are located. Mexico is a striking example. Given Mexico's proximity to the US and the tax breaks given to 'border industries'. we might expect the sales of US firms in Mexico back to the US market to be particularly large. On the contrary, the data indicate that such sales by manufacturing subsidiaries are in the neighbourhood of five per cent of total sales. Not all cases fit this 
pattern; in particular, US subsidiaries producing electronic equipment in the Far East export a large and growing share of their output to the US market. But these are the exceptions. The Mexican case is far closer to the norm.

This picture of the activities of US-based multinationals is at odds with an image widely held by critics of the companies' operations. The exploitation of cheap labour receives considerably more publicity that does market-directed activity. Recently, special attention has been focused on the tendency of some multinational firms to organise their production strategies on an international basis, to establish multiple sources for component parts, and to shift labour-intensive segments of manufacturing processes to the Third World. The term 'new international division of labour' is often used in this connection. Available data, however, do not support the contention that the role of US-based multinationals in establishing a 'new international division of labour' constitutes a central defining feature of their activity. When US-based manufacturing firms operating in the Third World are generally selling some 90 per cent of their output in local markets, it is difficult to maintain that these firms have established themselves in the poor countries primarily (or even largely) as part of some strategy - explicit or implicit - of 'rationalising' international production.

None of this is to deny that US workers in many parts of the country have lost their jobs as their employers have closed US operations and begun production abroad with cheaper labour. Indeed, entire communities have been devastated by this process. Moreover, because it only takes a few such moves to make the 'runaway shop' threat an effective bludgeon at the bargaining table, the magnitude of the problem is understated by the number of plant closures per se. Nonetheless, such movements are simply not the central factor in the overall operations of the multinationals.

The importance of stressing the market focus of US multinationals can be seen by recognising that this fact is also at odds with a view often expressed by apologists for the companies. Not infrequently, these firms are portrayed as great leaders, international engines of development, transforming and rationalising the world economy, and thus supplying more goods and more jobs for all affected. The reality rather seems to be that they are followers, that they go where markets are expanding. Instead of being aggressive actors, using their technology and capital to transform economies, they appear to be more conservative operators, following markets as they grow, not creating new avenues of prosperity.
When the international economy was expanding rapidly, the US-based multinationals expanded rapidly along with it. They developed a mode of operation then, however, that did not prepare them to deal with the changes that began to appear in the late $1960 \mathrm{~s}$ and became full blown in the 1970s. As market followers, they were not in a position to protect themselves from the general economic slowdown that took place. Things could have been different. Had the companies, for example, been oriented toward the US market and gone abroad for raw materials and cheap labour, their growth in the early era would not have been so rapid; but then their slowdown more recently would not have been so great, because the US economy slowed much less in the 1970s than did the economies of other advanced capitalist nations. Thus, the success of the early period and the relative failure of recent years are part and parcel of the same process. The companies got in to trouble at least in part because of the nature of their early success.

The clearest evidence that they 'got into trouble' is the substantial slowdown in their rate of expansion (noted above), but one could also cite how US multinational firms have fared relative to their rivals from, particularly, Japan and West Germany. Foreign investment by those rivals has been growing much more rapidly than that by US firms, and in virtually all industrial categories the domination of the market by US firms has been substantially reduced. Rising competition and the general slowdown of the international economy have forced many firms to undertake strategic readjustments. In particular, in the 1970s there was a rise in the frequency with which US-based multinationals accepted the imposition of joint ownership arrangements. The experience in Brazil stands out, but changes of the same sort also seem to have been pressed on the multinationals in several other Third World nations. Similarly, US firms increasingly have been forced to live with nationalisations, the overshadowing case being the experience in the oil industry. These sorts of developments do not always mean great losses for the multinationals - so far, at least, the oil companies have done quite well for themselves in the face of nationalisations and joint ventures. Yet these sorts of developments show how the position of the multinationals has changed since the early post-World War II era, and how that position is now characterised by considerable instability.

\section{III}

The ebb of activity by US-based multinational firms, however, has not been uniform. One branch of US business, in particular, has been highly successful at increasing its claims on wealth created elsewhere. Banking has become the most dynamic component of 
US business involvement in the international economy. In 1980, the interest received by US banks from foreign loans had risen to some $\$ 27$ bn from their 1970 level of less than $\$ 1$ bn. That $\$ 1$ bn in 1970 had been only one-tenth as great as the profits US-based multinationals were obtaining in that year from abroad; the 1980 interest receipts were 75 per cent as great as the multinationals' foreign-source profits.

US banks had not participated as much as one might expect in the early post-World War II expansion of US business abroad. Until the mid-1960s, their foreign operations grew relatively slowly. The growth of the US economy and the more rapid growth of US multinationals, which the banks could service from their domestic base, seem to have provided sufficient outlets for the banks. In the late 1960s and early 1970s, however, two major factors gave impetus to the international expansion of US-based banking: the tremendous increase in the availability of credit in the international system and the relative decline of profitable outlets for that credit in the advanced capitalist countries.

The increase in the availability of credit was a direct consequence of the way the US Government took advantage of its internationally hegemonic position to attempt to solve problems of the domestic economy. In order to finance its efforts to fight the war in Indochina while simultaneously buying off the urban rebellions against poverty and racism at home, the government expanded the supply of dollars. Since, under the sway of US hegemony, the international monetary system had been constructed after World War II on the principle that the dollar was as good as gold in international transactions, this extra supply of dollars was in turn used to pay off growing US obligations abroad. Thus an increasingly large supply of dollars built up overseas in the late $1960 \mathrm{~s}$, and this became the basis for the much discussed eurodollar market. US and foreign banks that held these dollars loaned them out without any of the constraints that go with lending in the US market itself. Each dollar could be lent, and then when it was deposited it could be re-lent again and again, creating an ever growing supply of credit, a huge volume of liquidity. In addition, when OPEC succeeded in raising oil prices in 1973, the system's liquidity was greatly increased as the oil exporting countries accumulated large surpluses that they held in dollars.

This growing supply of credit, however, could not be absorbed within the economies of the advanced capitalist countries. For in these economies, as the great post-World War II surge of economic expansion began to give out and as excess capacity developed internationally in major industries - especially steel and automobiles - profit rates fell. When the downturn of profit rates in the late 1960s became the crisis of the 1970s, investment growth slowed dramatically. In the US, the annual growth rate of gross investment fell from 4.8 per cent in the 1960 s to 1.6 per cent in the $1970 \mathrm{~s}$; in Japan, the fall was from 14.6 per cent to 3.2 per cent; and in West Germany, from 4.1 per cent to 1.6 per cent. With investment opportunities apparently lacking in the centre, and with actual investment growth slowing so greatly, the banks became mechanisms by which funds were 'pushed' out into the rest of the world.

This 'push' of funds from the centre to the periphery was, moreover, complemented by a 'pull'. The oil price increase was the most obvious source of the Third World's growing demand for credit, as oil-poor countries turned to the banks to finance their huge oil import bills. Oil events, however, were only a part of the story. Countries like Brazil, Mexico, Argentina and other heavy debtors have built their economies on a structure of dependence that has required them to take in increasing quantities of foreign capital in order to maintain growth. As long as their growth could be maintained, even with debt rising, there was no severe problem. Yet what happened at the end of the 1970s was bound to happen sooner or later. Recession again hit the world economy, and debtor countries could no longer count on strong export demand to provide the funds to pay off their debts.

These various forces - the 'pushes' and the 'pulls' affecting international credit - brought the international financial system to the precarious position of the early 1980s, with nations on the brink of bankruptcy and even people with the most remarkable faith in the viability of the system talking of panic and potential collapse. In November 1982, the Wall St. Journal used its front page to print a fictitious tale, a possible scenario, of financial collapse. The tale relates how the failure of a small Hong Kong bank, speculating in real estate, spreads until 'huge sums of money begin to move electronically around the world as banks, big investors, multinational companies, and Arab governments shift their dollars to 'safe havens' ... But, as the tale continues, big banks in the US and Europe also start to run out of funds, and finally the Journal writes: '. . gloom spreads through the world banking community as banks begin to fall like ninepins'. Although the Journal made it clear that this was 'an entirely fictitious scenario', it insisted that the events 'could happen'. It is difficult to judge the likelihood of an international banking crash of this sort and of the subsequent disastrous effects it would have upon production activity throughout the world. If a crash began to develop, the governments of the US and other wealthy capitalist nations along with the International Monetary Fund would surely step in and 
attempt to avert it. Yet there is no guarantee that such action would be sufficiently swift and effective.

In any case, the very fact that such a crash "could happen' makes a great deal of difference to the functioning of the international economy. When the threat of bankruptcy - and thus of crash - rises, interest rates also rise as lenders insist on getting a higher payment for the greater risk. Higher interest rates are hardly conducive to the economic expansion that might contribute to a solution to debtor countries' difficulties. Moreover, the austerity programmes that are imposed have the same sort of impact as do higher interest rates; they force continued slump rather than growth. Austerity programmes also raise considerably the likelihood of social and political conflicts. Finally, when governments do take actions to avoid a crash, they create other problems. Their only 'solution' is to provide more liquidity. This ean have the dual impact of pumping up the debt balloon even further - which may only postpone the day of reckoning - and of pushing inflation ahead even more rapidly.

Thus one need not postulate a high probability of financial collapse in order to see the disruptive implications of the growth of international banking. Simply the spectre of a crash has a major impact. Again, US business involvement in the international economy is such that success is tied to failure. The growth of international involvement by US banks in the 1970s was a very successful way in which US interests could claim a share of the world's wealth. That success, however, has engendered a structure of financial relations that makes the international economy more prone to severe instability.

\section{IV}

Faced with an unstable and hostile environment in which to pursue profits, large US firms have experienced internal problems that were unknown to them in the golden era of the 1950s and early 1960s. What is more, the organisational structures they established to operate in their tine of strength appear to be inappropriate to the new situation of instability.

ITT's experience is relevalt in this context. Through the early 1970s, ITT was able to grow rapidly by conglomeration. It needed a well co-ordinated system of organisation to handle the financial manipulations of such growth, and managers were "taught not to make things, but to make money'. The favourable growth circumstances of the period limited operational demands on ITT's management at the local level; it was relatively easy to expand production and sell the 'things'. Yet, by the middle of the 1970s, the situation had changed, and Fortune magazine, commenting on
ITT's poor profits in 1974, noted, 'In many ways the results of 1974 suggest the difficulty of managing and controlling a sprawling multinational complex'. ITT then elttered on a programme of selling off many of the subsidiaries it had acquired in its period of rapid conglomeration, giving evidence that it did not have the managerial organisation to handle such diverse holdings in hard times.

Other large firms also experienced managerial difficulties as instability beset the international economy in the late 1960s and early 1970s. In general, it appears that the very rapid international expansion by some firms in the 1950s and 1960s was an overexpansion, stretching companies beyond the capabilities of their organisational systems. Even the experience of General Electric (GE), a company noted both for its managerial acumen and successful international operations, illustrates the problem. In the late 1960s, GE was forced to curtail its drive in to European markets. To explain GE's difficulties, the business press cited poor management coordination in Europe, lack of internationally experienced exeeutives, lack of technical skills, and clumsy labour relations. The nature of GE's problems suggests that its European expansion and acquisitions policy was based on conditions that were ephemeral; the company did not have the capacity to deal with the more difficult - competitive and uncertain environment that emerged at the end of the 1960s.

It is widely recognised that the far-flung and complex activities of multinational enterprises, even when they are operating under the best of circumstances, demand extensive and sophisticated managerial structures. During the 1950 s and 1960 s, the era of US hegemony and of rapid international expansion of the US-based firms, the multinationals developed highly centralised, tightly controlled managerial structures. Subordinating the interests of the local units to the interests of the total firm, these structures allowed the firms a high degree of international flexibility which gave them great power. Centralised control gave the firms the ability to: reallocate financial resources among subsidiaries; establish marketing strategies within a company-wide plan; control research, development and innovation; minimise tax obligations through adjustments of internal pricing structures; rationalise production facilities to minimise costs on an international scale; and overcome political regulation through the threat of relocation.

Yet, while centralisation allowed international flexibility, it limited local flevibility. Subsidiaries of extensive US-based multinationals were not capable of responding effectively to local circumstances, whether those local circumstances involved changing market characteristics. new government regulations, 
or new forms of competition. Nonetheless, in the era of US hegemony, the firms faced little competition from Japan and Europe, and they had the overwhelming political authority of the US Government behind them; thus they did not experience serious difficulties from their lack of local flexibility. Hegemony and rapidly expanding markets meant that the highly centralised structures worked well.

As these circumstances changed during the 1970s, however, the US-based firms tended to remain caught in the organisational mode of earlier years. There is considerable inertia in the firms' practices, and they seem to be slow to adjust, especially when compared to their Japanese rivals. For example, centralised control structures produced a strong aversion to joint ownership arrangements by US-based firms. The aversion has been maintained, but firms from other advanced capitalist countries are generally more flexible. The US firms' approach is seen in IBM's practice of refusing to enter a country where it cannot maintain 100 per cent ownership. The Japanese, at the other extreme, sometimes appear to adopt a practice of taking any arrangement necessary to establish in a country and making the most of it. As a consequence of this difference in approach, a Japanese firm can have far-reaching connections in a Third World country through minority ownership in several companies, while a US firm with the same commitment of capital will be the full owner of one company. In reality, the former may have far more extensive de facto control, and the latter's operations may be hampered by its subsidiary's high profile as foreign owned.

The difference between US and other multinationals do not appear to be as great in their operations in the advanced countries. Nonetheless, there are differences that suggest that US firms continue to labour under the assumption that the rest of the world must adjust to them rather than they to the rest of the world. US firms still tend to drive for full ownership in the advanced countries; they do not easily accept worker participation programmes, such as co-determination; they have more labour conflicts than do other multinationals; and their local managers are endowed with less authority.

Many US-based firms, to be sure, have been doing quite well in their international operations, as is indicated by the substantial profits they are bringing from abroad. 'High tech' firms of various sorts probably provide the best examples. Still, it seems reasonable to assume that the sort of organisational problems illustrated above are, if not typical, at least widespread among US multinationals. In general, these companies have a common history in the international economy, and this common history has led them to develop similar sorts of strategies. The world economic crisis, moreover, presents them with common pressures. Where the consequent organisational contradictions are not manifest, they are likely to be latent and threatening.

In the 1980s, the firms need considerably more local flexibility, at least as much as they need to maintain international flexibility. Their organisational structures, however, are not designed to provide this. It is not at all clear how successfully and quickly the firms can adjust and overcome organisational inertia. Even if they were to adjust, this may not rectify the situation. The dominance of the international economy by US multinationals has been based in significant part on the advantages of their highly centralised structures, their tight control of an international system. Thus, if they give up some of that control in order to develop local flexibility, much of their advantage as multinationals is gone. They then become little different from large nationally operating firms, and foreign ownership may even prove to be a liability.

With US business and the US Government no longer hegemonic in the international system, centralisation is no longer so effective. At the very least, altered circumstances mean the continued relative decline of the US multinationals as they struggle to adjust and match the operations of their Japanese and European rivals that are not burdened by outmoded organisational structures. But further, if the extreme dominance of the multinationals has been based on the power they derived from their centralised structures, and if in today's world economy such structures no longer work so well, then the extreme dominance of the multinational firms is not likely to be maintained. Multinational firms remain tremendously powerful and important, but it is clear that their position in the international economy is changing significantly.

\section{V}

In a general sense, the economic disorder in the international system - and by extension the political disarray associated with that disorder - has been unavoidable. We did not get where we are because of either bad luck or bad policy. We got into the current mess as a result of the very process and particular nature of the long post-World War II economic expansion. The golden years of US hegemony, the success of an early period, produced the disorder, the failure of the current period. I have tried to argue this with each aspect of US international business I have discussed: the multinationals are in a weak position currently because, through their focus on markets, they were in a strong position earlier; the expansion of 
international banking was a successful response to the onset of general slow growth and inflation, a response that necessarily generated the current debt crisis; and the internal, organisational difficulties that are faced now by many multinationals are firmly tied to organisational successes of earlier years. This sort of analysis can be extended to cover the general difficulties that the US Government and US business are facing with regard to their international relations.

Such a line of reasoning leads one to recognise that the current debacle was not created by some wrongheaded policy choices in either Washington or corporate board rooms and, conversely, that things cannot be set right by the adoption of 'correct' policy. The Reagan Administration attributed the international problems of US business to the policies of past administrations. Accordingly, to 'revitalise' the US economy the Administration attempted to reestablish the extreme dominance of the US Government in international military and political affairs. Aside from the fact that this political goal is probably unattainable (and to say nothing of the fact that it is abhorrent), the policy would have a salutary impact on economic affairs only if the operations of US-based multinationals were basically sound, lacking only a favourable political context in order to surge forward once again. The analysis presented in this essay, however, suggests, to the contrary, that US firms themselves have created the conditions for their difficulties and that these difficulties are built into the basic structure of their operations.

Several people who offer alternatives to Reagan's faith in the wonders of private enterprise recognise that these serious problems have origins within the firms themselves. Accordingly, to re-establish the preeminence of US business these critics prescribe new approaches for management and government policies. These proposals are usually grouped under the rubric of 're-industrialisation' strategies, and they are often associated with liberal political perspectives. Reindustrialisation advocates might see the analysis made in this article as consistent with their own position. They recognise the insufficiently innovative strategies of many large firms, decry reckless behaviour by banks, and stress a need for firms to adopt managerial structures that are more flexible at the local level.

Yet the analysis here is fundamentally at odds with the re-industrialisation approach, which focuses on symptoms and gives scant attention to the deeper causes of the instability in which US-based multinationals have become enmeshed. In much of the reindustrialisation literature, managers are exhorted 'to be more flexible', 'to learn from the Japanese', and 'to be more far-sighted', as though the roots of the problem were insufficiently rigorous MBA (Master in Business Administration) programmes, lack of will, or just plain pigheadedness. In general, the call is for managers to correct their mistakes and do things 'right'. The argument in this article, however, is not that managers made 'mistakes'. They did not fail to succeed; on the contrary, they have been failing precisely because they did succeed.

My argument implies that policy reform, either at the governmental level or within the corporations, either 're-vitalisation' or 're-industrialisation', is likely to be ineffective in the current crisis. This is not to say that the crisis will continue indefinitely. International capitalism has experienced prior periods of crisis for example, during the 1930s and World War II and it is clear that the system can endure such disruptions. But, in addition, past experience also indicates that, however we come out of the current situation, the changes will be structural both within and between nations. Such changes are neither directly controllable nor easily foreseen. 